\title{
A Discussion for Women Empowerment in India
}

\author{
Dr Jai Prakash Tripathi ${ }^{1}$, Ms. Aafreen Roohi Qureshi ${ }^{2}$ \\ ${ }^{I}$ Dean, MBA, Sri Satya Sai University of Technology \& Medical Sciences, Sehore \\ ${ }^{2}$ Sri Satya Sai University of Technology \& Medical Sciences, Sehore
}

\begin{abstract}
Women Empowerment is an easy to refute subject. At prior time they were getting equivalent status with men. Yet, they had confronted a few troubles amid post-Vedic and epic ages. Numerous a periods they were dealt with as slave. From mid twenty century (national development) their statuses have been changed gradually and bit by bit. In such manner, we may specify the name of the British individuals. After then, autonomy of India, the sacred creators and national pioneers emphatically request parallel social position of ladies with men. Today we have seen the ladies possessed the respectable positions in all strolls of the fields. However, they have not completely liberated some segregation and provocation of the general public. A couple quantities of ladies have possessed the capacity to set up their possibilities. In this manner, each and everybody ought to be mindful so as to advance the ladies statuses.
\end{abstract}

Keywords: Women Empowerment; National Movement; Society.

\section{Presentation}

Women constitute just about half of the total populace however India has indicated unbalanced sex proportion whereby female's populace has been similarly lower than guys. To the extent their societal position is concerned, they are not regarded as equivalent to men in every one of the spots. In the Western social orders, the ladies have square with right and status with men in all kinds of different backgrounds. Be that as it may, sexual orientation inabilities and segregations are found in India even today. The dumbfounding circumstance has with the end goal that she was here and there worried as Goddess and at different circumstances only as slave.

\section{Women In India}

Presently the women in India appreciate a special status of fairness with the men according to sacred and legitimate arrangement. However, the Indian women have made considerable progress to accomplish the present positions. To begin with, sex disparity in India can be followed back to the notable days of Mahabharata when Draupadi was put on the dice by her better half as a product. History is a witness that ladies were made to move both in private and open spots to satisfy the man. Besides, in Indian culture, a female was constantly subject to male individuals from the family even most recent couple of years back. Thirdly, a female was not permitted to talk with boisterous voice within the sight of senior individuals from her in-laws. In the family, every deficiencies had gone to her and dependable. Forward, as a dowager her reliance on a male individual from the family still more increment. In numerous social exercises she is not allowed to blend with different individuals from the family. Other hand, she has next to no partaken in political, social and financial existence of the general public.

The mid twenty century, it was ascent of the National Movement under the initiative of Mahatma Gandhi who was supportive of evacuating every one of the inabilities of ladies. In the meantime, Raja Ram Mohan Rai, Iswar Chandra Vidyasagar and different other social reformers laid weight on ladies' instruction, counteractive action of youngster marriage, withdrawals of abhorrence routine of sati, evacuation of polygamy and so on. The National Movement and different change developments prepared for their freedoms from the social shades of malice and religious taboos. In this unique situation, we may expound on the Act of Sati (annul) 1829, Hindu Widow Remarriage Act' 1856, the Child Restriction Act, 1929, Women Property Right Act, 1937 and so on.

After freedom of India, the constitution creators and the national pioneers perceived the equivalent social position of ladies with men. The Hindu Marriage Act, 1955 has decided the age for marriage, accommodated monogamy and guardianship of the mother and allowed the disintegration of marriage under particular conditions. Under the Hindu Adoptions and Maintenance Act, 1956, an unmarried ladies, dowager or separation of sound personality can likewise take tyke in selection. So also, the Dowry Prohibition Act of 1961 says that any individual who gives, takes, or abets the giving or taking of share might be rebuffed with detainment, which may reach out to six months or fine up to Rs.5000/or with both. The Constitution of India ensures correspondence of genders and in reality allows unique favors to ladies. These can be found in three articles of the constitution. Article 14 says that the legislature should not deny to any individual uniformity under the steady gaze of law or equivalent insurance of the law. Article 15 announces that administration should 
not oppress any national on the ground of sex. Article 15 (3) Makes an extraordinary arrangement empowering the state to make positive segregations for ladies. Article 42 guides the state to make arrangement for guaranteeing just and human states of work and maternity help. Most importantly, the constitution respects a crucial obligation on each subject through Articles 15 (An), (E) to revoke the practices unfavorable to the poise of ladies.

\section{Strengthening of Women In India}

The idea of strengthening streams from the power. It is vesting where it doesn't exist or exist deficiently. Strengthening of women would mean preparing ladies to be financially free, confident, have positive regard to empower them to confront any troublesome circumstance and they ought to have the capacity to take an interest being developed exercises. The engaged ladies ought to have the capacity to take an interest during the time spent basic leadership. In India, the Ministry of Human Resource Development (MHRD-1985) and the National Commission for Women (NCW) have been attempted to protect the rights and legitimate qualification of ladies. The 73rd \&74th Amendments (1993) to the constitution of India have given some unique forces to ladies that for reservation of seats (33\%), though the report HRD as March2002 demonstrates that the lawmaking bodies with the most elevated rate of ladies are Sweden 42.7\%, Denmark 38\%, Finland 36\% and Iceland $34.9 \%$. In India "The New Panchayati Raj" is the piece of the push to engage ladies at any rate at the town level. The legislature of India has approved different worldwide traditions and human rights instruments resolving to secure equivalent rights to ladies. These are CEDAW (1993), the Mexico Plan of Action (1975), the Nairobi Forward Looking Strategies (1985), the Beijing Declaration and in addition the stage for Action (1995) and other such instruments. The time of 2001 was seen as the time of ladies' strengthening. Amid the year, a historic point archive has been received, 'the National Policy for the strengthening of ladies.' For the recipients of the ladies, the legislature has been embraced distinctive plans and projects i.e. the National Credit Fund for Women (1993), Food and Nutrition Board (FNB), Information and Mass Education (IMF) and so on.

The best advancement most recent couple of years have been the developing contribution of ladies in the Panchayati Raj foundations. There are many chosen ladies agents at the town committee level. At present all over India, there are add up to 20,56, 882 bands Gaon panchayat individuals, out of this ladies individuals is 8 , $38,244(40.48 \%)$, while add up to Anchalik panchayat individuals is $1,09,324$, out of this ladies individuals is $47,455,(40.41 \%)$ and add up to Zila parishad individuals is 11,708 , out of this ladies individuals is 4,923 $(42.05 \%)$. At the focal and state levels too ladies are continuously having any kind of effect. Today we have seen Women boss clergymen, ladies president, distinctive political gatherings pioneer, well build up representatives and so forth. The most striking among these are Mrs. Pratibha Devi Singh Patil, Sheela Dixit, Mayawati, Sonia Gandhi, Binda Karat, Nazma Heptullah, Indira Nuye (Pepsi-co), BJP pioneer Sushma Swaraj, Railway Minister Mamta Benarji, 'Narmada Basao' pioneer Medha Patekar, and Indian Iron Woman, Ex - Prime Minister Indira Gandhi and so on. Ladies are likewise including in human advancement issues of tyke raising, instruction, wellbeing, and sex equality. A large portion of them have gone into the making and showcasing of a scope of house items pickles, fitting, weaving and so on. The financial strengthening of ladies is being viewed nowadays as a sine-quo-non of advance for a nation; subsequently, the issue of monetary strengthening of ladies is of foremost significance to political scholars, social masterminds and reformers.

\section{Purposes Behind The Strengthening of Women}

Today we have seen diverse Acts and Schemes of the focal government and in addition state government to enable the ladies of India. Be that as it may, in India ladies are segregated and minimized at each level of the general public whether it is social interest, political support, financial investment, access to training, and furthermore regenerative human services. Ladies are observed to be financially exceptionally poor everywhere throughout the India. A couple of ladies are occupied with administrations and different exercises. Thus, they require monetary energy to remain all alone legs on per with men. Other hand, it has been watched that ladies are observed to be less proficient than men. As per 2001 registration, rate of proficiency among men in India is observed to be $76 \%$ though it is just 54\% among ladies. Hence, expanding training among ladies is of imperative in enabling them. It has additionally seen that some of ladies are excessively feeble, making it impossible to work. They devour less nourishment yet work more. In this manner, from the wellbeing perspective, ladies societies who are to be weaker are to be made more grounded. Another issue is that work environment badgering of ladies. There are such a large number of instances of assault, grabbing of young lady, endowment badgering, et cetera. Hence, they require strengthening of various sorts keeping in mind the end goal to ensure them-selves and to secure their immaculateness and respect.

\section{Conclusions}

To total up, ladies strengthening can not be conceivable unless ladies accompany and help to selfenable them-selves. There is a need to define lessening feminized neediness, advancing instruction of ladies, and 
aversion and disposal of brutality against ladies.

\section{References}

[1] Bright, Pritom Singh (edt)----Competition Refresher, August, 2010, New Delhi.

[2] Hasnain, Nadeem---Indian Society and Culture, Jawahar Publishers and Distributors, 2004.New Delhi.

[3] Kar, P. K---Indian Society, Kalyani Publishers, 2000, Cuttack.

[4] Kidwai, A. R----(edt)Higher Education, issues and challenges, Viva Books, 2010, New Delhi),

[5] Rao Shankar, C. N.----Indian Society, S.Chand \& Company Ltd, 2005, New Delhi. 